\title{
PENGARUH MODEL PEMBELAJARAN QUESTION STUDENT HAVE (QSH) BERBANTUAN PERMAINAN BINGO TERHADAP PEMAHAMAN KONSEP MATEMATIKA SISWA KELAS V DI SD TEGALJAYA
}

\author{
I Made Astra Winaya \\ Program Studi Pendidikan Guru Sekolah Dasar, Fakultas Keguruan dan Ilmu Pendidikan \\ Universitas Dwijendra Denpasar \\ astrawinayadwijendra@gmail.com \\ Putu Eka Kurniati \\ Program Studi Pendidikan Guru Sekolah Dasar, Fakultas Keguruan dan Ilmu Pendidikan \\ Universitas Dwijendra Denpasar \\ missecha19@gmail.com
}

\begin{abstract}
Abstrak
Penelitian ini dilatar belakangi oleh keinginan penulis untuk mengetahui perbedaan pemahaman konsep matematika siswa kelas V antara siswa yang mengikuti model pembelajaran Question Student Have (QSH) berbantuan permainan bingo dengan siswa yang mengikuti model pembelajaran konvensional. Penelitian ini dilaksanakan di SD Tegaljaya dengan populasi penelitian ini adalah seluruh siswa kelas V di SD Tegaljaya sejumlah 109 orang. Sampel dalam penelitian ini sebanyak 2 kelas, yaitu kelas eksperimen dan kelas kontrol yang terdiri atas 45 orang. Pengumpulan data dilakukan dengan menggunakan metode tes pemahaman konsep, observasi dan wawancara. Data yang diperoleh dianalisis menggunakan statistik deskriptif dan statistik inferensial, dengan uji-t. Berdasarkan analisis data dengan uji$\mathrm{t}$, diperoleh nilai $\mathrm{t}_{\text {hitung }}$ sebesar -2,704 dengan signifikansi (sig) sama dengan 0,011, sehingga nilai sig. (0,011) lebih kecil daripada taraf signifikansi 0,05. Hasil penelitian menunjukkan bahwa, terdapat perbedaan yang signifikan pemahaman konsep matematika siswa kelas V antara siswa yang mengikuti model pembelajaran Question Student Have (QSH) berbantuan permainan bingo dengan siswa yang mengikuti model pembelajaran konvensional. Hal ini menunjukkan model pembelajaran Question Student Have (QSH) berbantuan permainan bingo berpengaruh secara signifikan terhadap pemahaman konsep matematika siswa kelas V di SD Tegaljaya.
\end{abstract}

Kata kunci: question student have, bingo, pemahaman konsep matematika

\begin{abstract}
This research was motivated by the author's desire to find out the differences in understanding the mathematical concepts of fifth grade students between students who took the Question Student Have (QSH) learning model assisted by bingo games and students who took conventional learning models. This research was conducted at SD Tegaljaya with the population of this study were all students of fifth grade at SD Tegaljaya totaling 109 people. The sample in this study were 2 classes, namely the experimental class and the control class consisting of 45 people. The data was collected using the conceptual understanding test method, observation and interviews. The data obtained were analyzed using descriptive statistics and inferential statistics, with the t-test. Based on the data analysis with the t-test, the t-test value was -2.704 with a significance ( $\mathrm{sig}$ ) equal to 0.011 , so the sig value. (0.011) was smaller than the significance level of 0.05 . The results showed that, there was a significant difference in the understanding of the mathematical concepts of fifth grade students between students who took the Question Student Have (QSH) learning model assisted by bingo games and students who took conventional learning models. This showed that the Question
\end{abstract}




\section{WIDYA ACCARYA: Jurnal Kajian Pendidikan FKIP Universitas Dwijendra}

Vol 11 No 2, Oktober 2020

P ISSN: 2085-0018 E-ISSN: 2722-8339

Available Online at http://ejournal.undwi.ac.id/index.php/widyaaccarya/index

Student Have (QSH) learning model assisted by bingo games has a significant effect on the understanding of the mathematical concepts of fifth grade students at SD Tegaljaya.

Key words: question student have, bingo, understanding mathematical concepts

\section{PENDAHULUAN}

Pendidikan memiliki peran startegis dalam membangun sumber daya manusia yang berkualitas untuk dapat beradaptasi dengan tuntutan zaman. Untuk itu, pendidikan perlu mendapat perhatian dan dukungan dari seluruh stakeholder (I. M. A. dkk. Winaya, 2018). Berbagai upaya sedang dan telah dilakukan pemerintah guna meningkatkan mutu pendidikan di Indonesia. Salah satu aspek penting penunjang peningkatan mutu pendidikan adalah pembelajaran yang efektif dan berkualitas. Menurut Kyriacou (2009) mencakup dua hal pokok, yaitu waktu belajar aktif (active learning time) dan kualitas pembelajaran (quality of instruction). Hal yang pertama berkenaan dengan jumlah waktu yang dicurahkan oleh siswa selama dalam pelajaran berlangsung. Bagaimana para siswa terlibat dalam proses pembelajaran untuk mencapai tujuan yang diharapkan (Santika, 2017). Hal yang kedua berkaitan dengan kualitas aktual belajar itu sendiri. Artinya, bagaimana proses atau interaksi pembelajaran dapat berlangsung antara guru-siswa, siswa-siswa dan siswa-sumber belajar.

Guru sebagai ujung tombak dalam pelaksanaan pembelajaran, hendaknya mengupayakan pembelajaran yang bermakna bagi siswa melalui kreatifitas dan inovasi-inovasi pembelajaran yang membantu pencapaian sasaran dan tujuan pembelajaran. Menurut Adrian (2018) menjelaskan guru sebagai agen pembaharu (agent of change) adalah seseorang yang profesional yang mempengaruhi putusan inovasi terhadap peserta didik untuk meningkatkan kualitas kompetensinya. Untuk itu, dalam pembelajaran guru berperan sebagai motivator, pengelola kelas, mediator, fasilitator, observer, evaluator, dan administrator. Secara umum, siswa dikelas memiliki kemampuan yang tidak sama antara satu dengan yang lainnya oleh karenanya strategi merupakan salah satu factor yang akan mempengaruhi hasil belajar siswa. Dalam pembelajaran, kemampuan guru dalam memahami, memilih dan mengimplemntasikan model pembelajaran sangat berpengaruh terhadap pencapain tujuan pembelajaran (I. M. A. dkk. Winaya, 2018). Pencapaian tujuan pembelajaran sangat dipengaruhi oleh pemahaman konsep siswa terhadap materi yang sedang dipelajari.

Pemahaman konsep menjadi hal yang sangat penting dalam pembelajaran karena konsep merupakan dasar dari pengetahuan itu sendiri. Menurut Bloom (Vastari, 2009:16) pemahaman konsep adalah kemampuan menangkap pengertianpengertian seperti mampu mengungkap suatu materi yang disajikan kedalam bentuk yang lebih dipahami, mampu memberikan interpretasi dan mampu mengaplikasikannya. (Winaya, I Made Astra, 2019) mengungkapkan pemahaman siswa terhadap suatu konsep pembelajaran akan ditandai dengan 


\section{WIDYA ACCARYA: Jurnal Kajian Pendidikan FKIP Universitas Dwijendra}

Vol 11 No 2, Oktober 2020

P ISSN: 2085-0018 E-ISSN: 2722-8339

Available Online at http://ejournal.undwi.ac.id/index.php/widyaaccarya/index

kemampuan mampu memahami atau mengerti apa yang diajarkan, mengetahui apa yang sedang dikomunikasikan, memberi penjelasan atau memberi uraian yang lebih rinci dengan menggunakan bahasa sendiri ,maupun menyatakan ulang suatu konsep, mampu mengaplikasikan suatu objek dan mampu mengungkapkan suatu materi yang disajikan ke dalam bentuk yang lebih dipahami.

Pembelajaran matematika selama ini sering dianggap 'momok' bagi siswa karena matematika dianggap pelajaran yang sulit. Anggapan ini dipicu oleh berbagai faktor antara lain kemampuan guru dalam mengemas pembelajaran yang lebih menarik, kemampuan guru dalam mengembangkan dan memanfaatkan media, kemampuan guru dalam mengelola kelasnya (I. M. A. Winaya, 2020). Berdasarkan hasil observasi terhadap pembelajaran matematika di SD Tegaljaya diperoleh hasil bahwa 1) pembelajaran yang dilaksanakan belum memaksimalkan keterlibatan siswa secara aktif, 2) Pola pembelajaran masih didominasi pola pembelajaran ceramah dan kurangnya pemanfatan media pembelajaran, 3) siswa kurang termotivasi untuk bertanya, 4) terlihat ragu dalam menjawab pertanyaan, 5) kurangnya antusiasmen siswa dalam kegiatan pembelajran yang berimplikasi terhadap rendahnya rasa ingin tahu siswa dan cenderung pasif (Widiastuti \& Winaya, 2019). Hasil observasi ini diperkuat dengan hasil wawancara dengan pihak guru. Guru menyampaikan keluhanya tentang banyaknya tugas adinistarsi yang harus dikerjakan, sehinga membuat kegiatan pembelajaran tidak dapat dilakukan secara optimal. Selain itu, kurangnya kompetensi dalam pebuatan dan pemanfaatan media pembelajaran berimpilikasi belum optimalnya penggunaan media dalam pembelajaran.

Berdasarkan permasalahan tersbut, dibutuhkan sebuah model pembelajaran yang inovatif sebagai sebuah laternatif pemecahan masalah. Pemilihan model pembelajaran yang tepat akan mampu mempengaruhi pencapaian tujuan pembelajaran. Salah satu model pembelajaran yang dapat digunakan untuk meningkatkan pemahaman kosep siswa dalam pembelajaran matematika adalah model pembelajaran Question Student Have (QSH). Hal ini sejalan dengan hasil penelitian (Tegeh \& Budiartini, 2017) menunjukan bahwa, terdapat perbedaan yang signifikan hasil belajar IPA antara siswa yang mengikuti model pembelajaran Question Student Have (QSH) berbantuan permainan ular tangga dengan siswa yang mengikuti model pembelajaran konvensional. Dalam penelitian ini, peneliti memiliki keinginan kuat untuk menguji perbedaan pemahaman konsep matematika siswa kelas V antara siswa yang mengikuti model pembelajaran Question Student Have (QSH) berbantuan permainan bingo dengan siswa yang mengikuti model pembelajaran konvensional.

Model pembelajaran QSH adalah salah satu model pengembangan dari model pembelajaran PAKEM yang dikembangkan untuk melatih siswa agar memiliki kemampuan dan keterampilan bertanya (Hafidh, 2010). Model pembelajaran QSH dikembangkan untuk melatih siswa agar memiliki kemampuan dan keterampilan bertanya. Model pembelajaran QSH mengharuskan siswa-siswi untuk menuliskan pertanyaan-pertanyaan mengenai materi 


\section{WIDYA ACCARYA: Jurnal Kajian Pendidikan FKIP Universitas Dwijendra}

Vol 11 No 2, Oktober 2020

P ISSN: 2085-0018 E-ISSN: 2722-8339

Available Online at http://ejournal.undwi.ac.id/index.php/widyaaccarya/index

pelajaran yang tidak dipahami dalam bentuk lembaran-lembaran kertas, kemudian memberikan kesempatan kepada teman-teman yang lain untuk membaca pertanyaan yang telah ada.

Tujuan dari model QSH yaitu mendorong siswa untuk berpikir dalam memecahkan masalah suatu soal, menyelediki dan menilai penguasaan siswa tentang bahan pelajaran, membangkitkan minat siswa sehingga akan menimbulkan keinginan untuk mempelajarinya dan juga menarik perhatian siswa dalam belajar (Wahyuningsih, dkk). Selain model pembelajaran QSH hal yang dapat menunjang proses pembelajaran yaitu adanya media permainan. Permainan merupakan salah satu media yang bisa diterapkan dalam proses pembelajaran. Kegiatan permainan memberikan kesempatan pada semua siswa untuk terlibat langsung dalam proses pembelajaran. Salah satunya adalah permainan bingo, permainan ini merupakan permainan papan untuk anak-anak yang dimainkan oleh dua orang atau lebih. Strategi permainan bingo merupakan jenis permainan atraktif yang melibatkan anak berperan aktif dalam bingo. Permainan bingo dapat digunakan pada semua mata pelajaran. Kuatnya pola interaksi aktivitas siswa saat memainkan permainan bingo dalam kegiatan pembelajaran menyebabkan permainan ini sangat disenangi oleh siswa. Hal ini sejalan dengan pendapat (Chang \& Cogswell, 2008) yang mengungkapkan menemukan permainan yang sederhana dan sesuai dengan pembelajaran, guru akan bisa menghemat waktu dan tenaga. Bingo merupakan salah satu permainan dalam pembelajaran Matematika yang memberikan kesempatan pada anak untuk berinteraksi dan berkompetisi dengan temannya. Berdasarkan uraian sebelumnya, pengkolaborasian model pembelajaran Question Student Have (QSH) dengan permainan bingo diayakini dapat mengoptimalkan pemahaman konsep siswa.

\section{METODE PENELITIAN}

Jenis penelitian ini termasuk jenis quasi experiment atau eksperimen semu yaitu pengambilan sampel dari populasi yang ada diadakan secara random pada tingkat kelas dan bukan pada tingkat siswa secara individu. Rancangan penelitian yang digunakan adalah "Non-equivalen Post Test Only Control Group Design.

Tabel 01 Non Equivalent Post-test Only Control Group Design

\begin{tabular}{|c|c|c|}
\hline Kelas & Treatment & Post-test \\
\hline E & $\mathrm{X}_{1}$ & $\mathrm{O}_{1}$ \\
\hline
\end{tabular}




\begin{tabular}{|l|l|l|}
\hline $\mathrm{K}$ & $\mathrm{X}_{2}$ & $\mathrm{O}_{2}$ \\
\hline
\end{tabular}

(Dimodifikasi dari Sugiyono, 2013)

Keterangan:

$\mathrm{E} \quad=$ kelompok eksperimen

$\mathrm{K} \quad=$ kelompok kontrol

$\mathrm{O}_{1}=$ post-test terhadap kelompok eksperimen

$\mathrm{O}_{2} \quad$ post-test terhadap kelompok kontrol
$\mathrm{X}_{1}=$ treatment terhadap kelompok eksperimen (model pembelajaran kooperatif tipe questions student have berbantuan permainan ular tangga)

$\mathrm{X}_{2}=$ treatment terhadap kelompok kontrol (model pembelajaran konvensional)

Populasi dalam penelitian ini adalah seluruh siswa kelas V pararel di SD Tegaljaya. Adapu

Tabel 02 Komposisi Anggota Populasi

\begin{tabular}{|c|c|c|}
\hline No & Nama Kelas & Jumlah Siswa Kelas IV \\
\hline 1 & Kelas VA & 31 \\
\hline 2 & Kelas VB & 33 \\
\hline 3 & Kelas VC & 22 \\
\hline 4 & Kelas VD & 23 \\
\hline
\end{tabular}


Pengambilan sampel dalam penelitian ini dilakukan dengan random sampling, dengan teknik undian. Pada tahap pertama, seluruh kelas V SD Tegaljaya dilakukan uji kesetaraan sampel, dengan menggunakan rata-rata ulangan tengah semester mata pelajaran matematika. Tes kesetaraan dianalisis dengan uji ANAVA satu jalur. Uji ANAVA satu jalur dimaksudkan untuk mengetahui ada tidaknya perbedaan skor rerata ulangan tengah semester pada mata pelajaran matematika, di samping itu untuk meyakinkan bahwa kelas yang dijadikan sampel merupakan kelas yang setara. Dari hasil tersebut dinyatakan kelas VC sebagai kelas eksperimen dan kelas VD sebagai kelas kontrol.

Variabel bebas dalam penelitian ini adalah pembelajaran yang terdiri dari dua dimensi yaitu, pembelajaran menggunakan model pembelajaran Question Student Have (QSH) berbantuan permainan bingo dan pembelajaran konvensional. Sedangkan variabel terikat dalam penelitian ini adalah pemahman konsep matematika siswa kelas V. Data yang dikumpulkan yaitu data yang ingin didapatkan sebagai variabel terikat yaitu pemahaman konsep. Instrumen yang digunakan untuk memperoleh data tentang pemahaman konsep siswa dalam penelitian ini berupa lembar tes pilihan ganda mata pelajaran matematika dengan empat kemungkinan jawaban yang tepat.

\section{HASIL DAN PEMBAHASAN}

Data penelitian ini adalah skor pemahaman konsep matematika siswa sebagai implikasi dari pengaruh model pembelajaran Question Student Have $(Q S H)$ berbantuan permainan bingo pada kelompok eksperimen. Data pemahaman konsep yang diperoleh melalui post-test terhadap siswa pada kelas eksperimen menunjukkan bahwa skor tertinggi adalah 100 dan skor terendah adalah 65. Berdasarkan hasil penelitian tersebut dapat dideskripsikan mean (M), median (Me), modus (Mo), varians, dan standar deviasi (s) dari data hasil hasil belajar IPA kelompok eksperimen, yaitu mean $(\mathrm{M})=82,94$, median $(\mathrm{Me})=$ $82 \operatorname{modus}(\mathrm{Mo})=82$, varians $\left(\mathrm{s}^{2}\right)=127,56$ dan standar $\operatorname{deviasi}(\mathrm{s})=11,29$.

Data pemahaman kelompok eksperimen dapat disajikan ke dalam bentuk histogram seperti pada Grafik 01, berikut. 


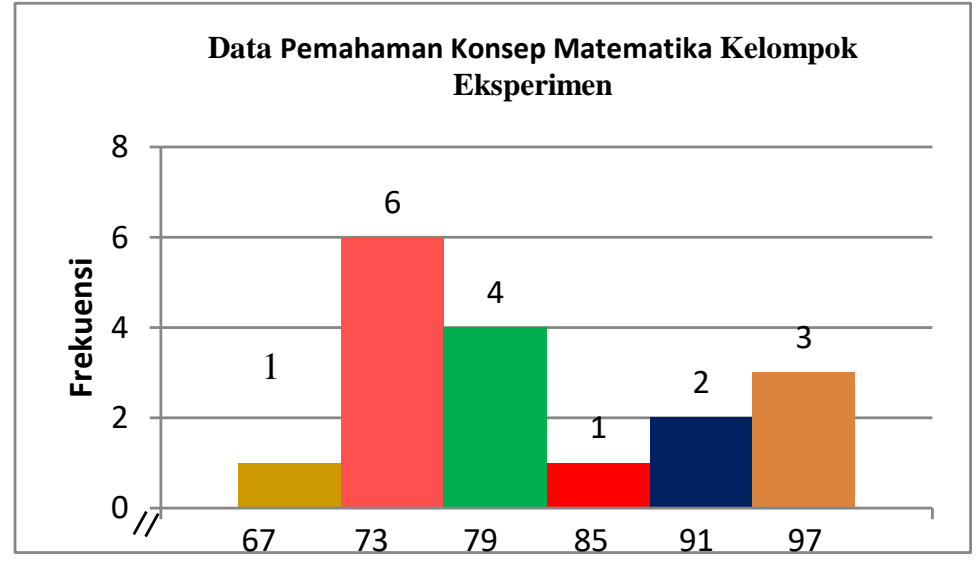

\section{Grafik 01 Histogram Pemahaman Konsep Matematika Siswa Kelompok Eksperimen}

Berdasarkan Grafik 4.1, menunjukkan bahwa rata-rata pemahaman konsep siswa pada kelompok eksperimen yang memperoleh skor 67,5 menunjukkan bahwa sebanyak $5,88 \%$ siswa memperoleh skor di dibawah rata-rata. Rata-rata hasil belajar matematika siswa yang memperoleh skor 73,5 dengan frekuensi 6 menunjukkan bahwa sebanyak $35,29 \%$ siswa memperoleh skor disekitar rata-rata. Rata-rata pemahaman konsep matematika siswa yang memperoleh skor 79,5 dengan frekuensi 4 menunjukkan bahwa sebanyak $23,52 \%$ siswa memperoleh skor diatas rata-rata. Pada skor 85,5 dengan frekuensi 1 rata-rata pemahan konsep matematika siswa menunjukkan bahwa sebanyak $5,88 \%$ siswa memperoleh skor diatas rata-rata. Pada skor 91,5 dengan frekuensi 2 rata-rata pemahan konsep siswa menunjukkan bahwa sebanyak 11,76\% siswa memperoleh skor diatas rata-rata. Pada skor 97,5 dengan frekuensi 3 rata-rata pemahaman konsep matematika siswa Hal ini menunjukkan bahwa sebanyak $17,64 \%$ siswa memperoleh skor diatas ratarata.

Pada Grafik 01 memberikan gambaran tentang tinggi rendahnya variabel pemahaman konsep matematika siswa, selanjutnya skor rata-rata pemahaman konsep matematika siswa dikonversikan dengan menggunakan kriteria rata-rata ideal $\left(\mathrm{M}_{\mathrm{i}}\right)$ dan standar deviasi ideal $\left(\mathrm{SD}_{\mathrm{i}}\right)$. Dari hasil perhitungan $\mathrm{M}_{\mathrm{i}}$ dan $\mathrm{SD}_{\mathrm{i}}$ maka diperoleh hasil konversi seperti pada Tabel 04 berikut ini.

Tabel 04 Hasil Konversi Pemahaman Konsep matematika Siswa Kelompok Eksperimen pada Skala Penilaian
Rentang Skor
Kategori 


\begin{tabular}{|c|c|}
\hline $12,75 \leq \mathrm{M} \leq 17$ & Sangat Tinggi \\
\hline $9,91 \leq \mathrm{M} \leq 12,75$ & Tinggi \\
\hline $7,09 \leq \mathrm{M} \leq 9,91$ & Sedang \\
\hline $4,25 \leq \mathrm{M} \leq 7,09$ & Rendah \\
\hline $0 \quad \leq \mathrm{M} \leq 4,25$ & Sangat Rendah \\
\hline
\end{tabular}

Berdasarkan hasil konversi pada Tabel 04. diperoleh bahwa skor rata-rata pemahaman konsep matematika siswa kelompok eksperimen dengan $\mathrm{M}=$ 82,94 tergolong kategori sedang. Data pemahaman konsep matematika siswa yang diperoleh melalui posttest menunjukkan bahwa skor tertinggi adalah 100 dan skor terendah adalah 35. Berdasarkan hasil penelitian dapat dideskripsikan mean (M), median
(Me), modus (Mo), varians, dan standar deviasi (s) dari hasil belajar IPA siswa kelompok kontrol, yaitu mean $(\mathrm{M})=68,94$, median $(\mathrm{Me})=71 \operatorname{modus}(\mathrm{Mo})=71$ varians $\left(\mathrm{s}^{2}\right)=328,05$, dan standar deviasi $(\mathrm{s})=18,11$.

Data hasil pemahamn konsep kelompok kontrol dapat disajikan ke dalam bentuk histagram seperti pada Grafik 02

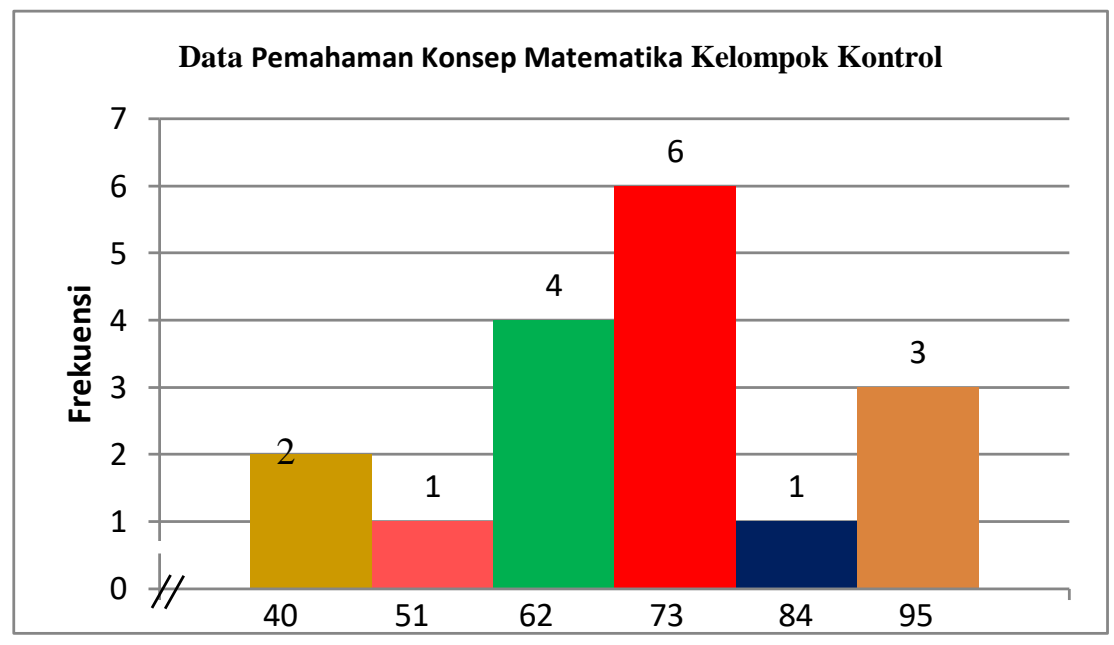

Grafik 02 Histogram Data Pemahaman Konsep Matematika Siswa Kelompok Kontrol

Pada Grafik 0.2, menunjukkan bahwa rata-rata pemahaman konsep siswa pada kelompok kontrol pada skor 40 dengan frekuensi 2 menunjukkan bahwa sebanyak 11,76\% siswa memperoleh skor di dibawah rata-rata. Pada skor 51 dengan frekuensi 1 rata-rata pemahaman konsep matematika siswa menunjukkan bahwa sebanyak 5,88\% siswa memperoleh skor dibawah rata-rata. Rata-rata pemahaman konsep 


\section{WIDYA ACCARYA: Jurnal Kajian Pendidikan FKIP Universitas Dwijendra}

Vol 11 No 2, Oktober 2020

P ISSN: 2085-0018 E-ISSN: 2722-8339

Available Online at http://ejournal.undwi.ac.id/index.php/widyaaccarya/index

siswa yang memperoleh skor 62 dengan frekuensi 4 menunjukkan bahwa sebanyak $23,52 \%$ siswa memperoleh skor dibawah rata-rata. Rata-rata pemahaman konsep matematika siswa yang memperoleh skor 73 dengan frekuensi 6 menunjukkan bahwa sebanyak 35,29\% siswa memperoleh skor di sekitar rata-rata. Pada skor 73 dengan frekuensi 1 rata-rata pemahaman konsep matematika siswa menunjukkan bahwa sebanyak $5,88 \%$ siswa memperoleh skor diatas rata-rata. Rata-rata pemahaman konsep matematika siswa yang memperoleh skor 84 dengan frekuensi 3 menunjukkan bahwa sebanyak $17,64 \%$ siswa memperoleh skor diatas rata-rata.

Berdasarkan Grafik 4.2, untuk mengetahui tinggi rendahnya variabel pemahaman konsep matematika siswa, skor rata-rata pemahamn konsep matematika siswa dikonversikan dengan menggunakan kriteria rata-rata ideal $\left(\mathrm{M}_{\mathrm{i}}\right)$ dan standar deviasi ideal $\left(\mathrm{SD}_{\mathrm{i}}\right)$. Dari hasil perhitungan $\mathrm{M}_{\mathrm{i}}$ dan $\mathrm{SD}_{\mathrm{i}}$ maka diperoleh hasil konversi seperti pada Tabel 4.5

Tabel 5. Hasil Konversi Pemahamn Konsep Matematika Siswa Kelompok Kontrol Pada Skala Penilaian

\begin{tabular}{|c|c|}
\hline Rentang Skor & Kategori \\
\hline $12,75 \leq \mathrm{M} \leq 17$ & Sangat Tinggi \\
\hline $9,91 \leq \mathrm{M} \leq 12,75$ & Tinggi \\
\hline $7,09 \leq \mathrm{M} \leq 9,91$ & Sedang \\
\hline $4,25 \leq \mathrm{M} \leq 7,09$ & Rendah \\
\hline $0 \quad \leq \mathrm{M} \leq 4,25$ & Sangat Rendah \\
\hline
\end{tabular}

Hasil konversi pada Tabel 05. diperoleh bahwa skor rata-rata pemahaman konsep matematika siswa kelompok kontrol dengan $\mathrm{M}=68,94$ tergolong kategori rendah. Untuk mengetahui ada tidaknya perbedaan pemahaman konsep matematika siswa antara model pembelajaran Question Student Have (QSH) berbantuan permainan bingo dengan model pembelajaran konvensional maka dilakukan uji hipotesis terlebih dahulu, sebelum uji hipotesis dilakukan, terlebih dahulu dilakukan pengujian prasyarat terhadap sebaran data yang meliputi uji normalitas dan uji homogenitas.

1. Uji Normalitas data

Uji Normalitas data dimaksudkan untuk memperlihatkan bahwa data sampel berasal dari populasi yang berdistribusi normal. Berdasarkan analisis data yang dilakukan, dapat disajikan hasil uji normalitas sebaran data pemahaman konsep matematika kelompok eksperimen dan kontrol pada Tabel 06 dengan dibantu program SPSS Version 19.

Tabel 06. Hasil Uji Normalitas Distribusi Data Pemahaman Konsep Matematika Pada Kelompok Kontrol 


\begin{tabular}{|c|c|c|c|c|c|c|}
\hline \multicolumn{7}{|c|}{ Tests of Normality } \\
\hline & \multicolumn{3}{|c|}{$\overline{\text { Kolmogorov-Smimov }}$} & \multicolumn{3}{|c|}{ Shapiro-Wilk } \\
\hline & Statistic & Df & Sig. & Statistic & Df & Sig. \\
\hline Kontrol & 0,161 & 17 & 0,200 & 0,941 & 17 & 0,329 \\
\hline \multicolumn{7}{|c|}{ a. Lilliefors Significance Correction } \\
\hline \multicolumn{7}{|c|}{ - This is a lower bound of the true significance. } \\
\hline
\end{tabular}

Tabel 07. Hasil Uji Normalitas Distribusi Data Pemahaman Konsep Matematika Pada Kelompok Eksperimen

Tests of Normality

\begin{tabular}{|c|c|c|c|c|c|c|}
\hline \multirow{2}{*}{} & \multicolumn{3}{|c|}{ Kolmogorov-Smirnov $^{\mathrm{a}}$} & \multicolumn{3}{|c|}{ Shapiro-Wilk } \\
\cline { 2 - 7 } & Statistic & Df & Sig. & Statistic & Df & Sig. \\
\hline Eks. & 0,180 & 17 & 0,145 & 0,920 & 17 & 0,145 \\
\hline
\end{tabular}

Berdasarkan hasil pengujian bilangan statistik dengan menggunakan rumus KolmogorovSmirnov pada kelas kontrol diperoleh 0,161 dengan bilangan signifikansi besarnya 0,200 . Hal ini berarti, bilangan signifikansi ( $s i g$ ) lebih besar daripada taraf signifikansi, maka bilangan statistik yang diperoleh signifikan. Sehingga data pemahaman konsep matematika siswa kelompok kontrol berdistribusi normal. Sedangkan, untuk data pemahamn konsep matematika siswa kelompok eksperimen, diperoleh hasil 0,180 dengan bilangan signifikansi besarnya 0,145 . Hal ini berarti, bilangan signifikansi (sig) lebih besar daripada taraf signifikansi, maka bilangan statistik yang diperoleh signifikan. Sehingga data pemahaman konsep matematika siswa kelompok eksperimen berdistribusi normal

1. Uji homogenitas

Uji Homogenitas dimaksudkan untuk memperlihatkan bahwa dua atau lebih kelompok data sampel berasal dari populasi yang memiliki variansi yang sama (Candiasa, 2004: 8). Uji homogenitas dilakukan terhadap varians pasangan antar kelompok eksperimen dan kontrol. Rangkuman hasil uji homogenitas varians antar kelompok eksperimen dan kontrol disajikan pada Tabel 08. 
Tabel 08. Hasil Uji Homogenitas Varians antara Kelompok Eksperimen dan Kontrol dengan Program SPSS Version 19

Levene's Test of Equality of Error Variances ${ }^{\mathrm{a}}$

Dependent Variable:Hasil Belajar

\begin{tabular}{|c|c|c|c|}
\hline $\mathrm{F}$ & $\mathrm{df1}$ & $\mathrm{df} 2$ & Sig. \\
\hline 1,426 & 1 & 32 & 0,241 \\
\hline
\end{tabular}

Tests the null hypothesis that the error variance of the dependent variable is equal across groups.

a. Design: Intercept + Model

Berdasarkan Tabel 08. diketahui nilai $\mathrm{F}=$ 1,426 dengan dk pembilang $1 \mathrm{dan} \mathrm{dk}$ penyebut $32 \mathrm{dan}$ nilai signifikansi $($ sig $)=0,241$ dan taraf signifikansi 0,05 . Hal ini berarti nilai sig. jauh lebih besar daripada taraf signifikansi sehingga varians data pemahaman konsep matematika siswa kelompok eksperimen dan kontrol adalah homogen.

Berdasarkan uji prasyarat analisis data, diperoleh bahwa data pemahaman konsep matematika kelompok eksperimen dan kontrol adalah normal dan varians kedua kelompok homogen. Untuk itu, pengujian hipotesis dilakukan dengan menggunakan uji-t sampel independent (tidak berkorelasi). Rangkuman hasil perhitungan uji-t antar kelompok eksperimen dan kontrol disajikan pada Tabel 09.

\section{Tabel 4.9 Rangkuman Hasil Perhitungan Uji-t dengan Program SPSS Version 19}

\begin{tabular}{|c|c|c|c|c|c|c|c|c|c|c|}
\hline \multicolumn{11}{|c|}{ Independent Samples Test } \\
\hline & & \multicolumn{2}{|c|}{$\begin{array}{l}\text { Levene's Test } \\
\text { for Equality of } \\
\text { Variances }\end{array}$} & \multicolumn{7}{|c|}{ t-test for Equality of Means } \\
\hline & & \multirow[b]{2}{*}{ F } & \multirow[b]{2}{*}{ Sig. } & \multirow[b]{2}{*}{ T } & \multirow[b]{2}{*}{ Df } & \multirow{2}{*}{$\begin{array}{c}\text { Sig. } \\
\text { (2-tailed) }\end{array}$} & \multirow{2}{*}{$\begin{array}{l}\text { Mean } \\
\text { Difference }\end{array}$} & \multirow{2}{*}{$\begin{array}{c}\text { Std. Error } \\
\text { Differenc } \\
e\end{array}$} & \multicolumn{2}{|c|}{$\begin{array}{l}95 \% \text { Confidence Interval } \\
\text { of the Difference }\end{array}$} \\
\hline & & & & & & & & & Lower & Upper \\
\hline \multirow{2}{*}{$\begin{array}{l}\text { Hasil } \\
\text { Belajar }\end{array}$} & \begin{tabular}{|l|} 
Equal \\
variances \\
assumed
\end{tabular} & 1,426 & 0,241 & $-2,704$ & 32 & 0,011 & $-14,00000$ & 5,17697 & $-24,54515$ & $-3,45485$ \\
\hline & $\begin{array}{l}\text { Equal } \\
\text { variances } \\
\text { not } \\
\text { assumed }\end{array}$ & & & $-2,704$ & 26,808 & 0,012 & $-14,00000$ & 5,17697 & $-24,62582$ & $-3,37418$ \\
\hline
\end{tabular}




\section{WIDYA ACCARYA: Jurnal Kajian Pendidikan FKIP Universitas Dwijendra}

Vol 11 No 2, Oktober 2020

P ISSN: 2085-0018 E-ISSN: 2722-8339

Available Online at http://ejournal.undwi.ac.id/index.php/widyaaccarya/index

Berdasarkan tabel hasil perhitungan uji-t di atas, menunjukkan bahwa hasil pengujian homogenitas data dengan uji Levene mendapatkan koefisien $\mathrm{F}$ sebesar 1,426 dengan signifikansi (sig) sebesar 0,241 dengan taraf signifikansi 0,05.Dengan demikian data dari kedua sampel homogen. Hasil uji t mendapatkan $\mathrm{t}$ hitung sebesar $-2,704$ dengan signifikansi (sig) sama dengan 0,011 . Sehingga nilai sig. $(0,011)$ jauh lebih kecil daripada taraf signifikansi 0,05. Dengan demikian $\mathbf{H}_{\mathbf{0}}$ ditolak dan $\mathbf{H}_{\mathbf{1}}$ diterima. Jadi terdapat perbedaan yang signifikan pemahaman konsep matematika siswa kelas $\mathrm{V}$ antara siswa yang mengikuti model pembelajaran Question Student Have $(Q S H)$ berbantuan permainan bingo dengan siswa yang mengikuti model pembelajaran konvensional di SD Tegaljaya.

\section{SIMPULAN}

Berdasarkan hasil pengujian hipotesis dan pembahasan, maka simpulan penelitian ini menyatakan bahwa, 1) Pemahaman konsep matematika siswa yang dibelajarkan dengan model pembelajaran Question Student Have (QSH) berbantuan permainan bingo adalah $\mathrm{M}=82,94$, jika dikonversi ke dalam skala penilaian pada skala lima berada pada kategori sangat tinggi. Pada grafik histogram menunjukkan bahwa sebagian besar skor cenderung tinggi. 2) Pemahaman konsep matematika siswa yang dibelajarkan dengan model pembelajaran konvensional cenderung lebih rendah daripada siswa yag dibelajarkan dengan model pembelajaran
Question Student Have (QSH) berbantuan permainan bingo dengan $\mathrm{M}=68,94$, jika dikonversi ke dalam skala penilaian pada skala lima berada pada kategori tinggi. Pada grafik histogram menunjukkan bahwa sebagian besar skor cenderung rendah. 3) Terdapat perbedaan yang signifikan pemahaman konsep matematika siswa kelas $\mathrm{V}$ antara siswa yang mengikuti model pembelajaran Question Student Have $(Q S H)$ berbantuan permainan bingo dengan siswa yang mengikuti model pembelajaran konvensional di SD Tegaljaya. Hal tersebut berdasarkan hasil perhitungan uji-t yang menunjukkan bahwa hasil pengujian homogenitas data dengan uji Levene mendapatkan koefisien $\mathrm{F}$ sebesar 1,426 dengan signifikansi (sig) sebesar 0,241 dengan taraf signifikansi 0,05. Dengan demikian data dari kedua sampel homogen. Hasil uji $\mathrm{t}$ mendapatkan $\mathrm{t}$ hitung sebesar -2,704 dengan signifikansi (sig) sama dengan 0,011 . Sehingga nilai sig. $(0,011)$ jauh lebih kecil daripada taraf signifikansi 0,05. Dengan demikian $\mathrm{H}_{0}$ ditolak dan $\mathrm{H}_{1}$ diterima. Hal ini menunjukkan model pembelajaran Question Student Have (QSH) berbantuan permainan bingo berpengaruh secara signifikan terhadap pemahman konsep matematika siswa. Berdasarkan pengalaman penelitian yang telah dilakukan, peneliti menyarankan guru untuk mengggunakan model pembelajaran inovatif dan mengkombinasikan dengan penggunaan media pembelajaran interaktif yang sesuai dengan tujuan pembelajaran. keterlibatan siswa secara aktif dalam pemembelajaran memberikan pengalaman langsung 
WIDYA ACCARYA: Jurnal Kajian Pendidikan FKIP Universitas Dwijendra

Vol 11 No 2, Oktober 2020

P ISSN: 2085-0018 E-ISSN: 2722-8339

Available Online at http://ejournal.undwi.ac.id/index.php/widyaaccarya/index

dalam menemukan maupun memecahkan masalah dan meningkatkan pemahaman konsep pembelajaran yang diberikan.

\section{DAFTAR PUSTAKA}

Candiasa, I Made. 2011. Statistik Multivariat Disertai Aplikasi SPSS. Singaraja: Undiksha Press.

Candiasa, I Made. 2010. Statistik Univariat dan Bivariat Disertai Aplikasi SPSS. Singaraja: Undiksha.

Chang, S \& Cogswell, J. 2008. Using Board Games in the Language Classroom. New York: TESOL Conversion and Exhibition

Kyriacou, C. 2009. Effective Teaching in Schools: Theory and Practice. Third Edition. Delta Place, Cheltenham, UK: Nelson Thornes Ltd

Said, Alamsyah dkk. 2015. 95 Strategi Mengajar Multiple Intelligences. Cetakan Ke- 1. Jakarta: Kencana Prenadamedia Group.

Santika, I Gusti Ngurah. 2017. Kepala Sekolah Dalam Konsep Kepemimpinan Pendidikan: Suatu Kajian Teoritis. Widya Accarya. 7 (1).

Subawa, I Made. 2012. Pengaruh Penerapan Model Pembelajaran Kooperatif Questions Student Have Dan Think Pair Share Terhadap Pemahaman Konsep Kimia Dan Keterampilan Berpikir Kritis Siswa. Jurnal Universitas Pendidikan Ganesha.Singaraja

Sugiyono. 2012. Metode Penelitian Pendidikan: Pendekatan Kuantitatif, Kualitatif dan $R$ \& D. Cetakan Ke-14. Bandung: Alpabeta.

Tegeh, M., \& Budiartini, N. K. S. (2017). Pengaruh Model Pembelajaran Question Student Have (Qsh) Berbantuan Permainan Ular Tangga Terhadap Hasil Belajar Ipa. International Journal of Elementary Education, 1(2), 137. https://doi.org/10.23887/ijee.v1i2.11606

Widiastuti, N. L. G. K., \& Winaya, I. M. A. (2019).
Prinsip Khusus Dan Jenis Layanan Pendidikan Bagi Anak Tunagrahita. Jurnal Santiaji Pendidikan (JSP), 9(2), 116-126. https://doi.org/10.36733/jsp.v9i2.392

Winaya, I Made Astra, N. K. K. (2019). Penerapan Model Pembelajaran Kooperatif Tipe Think Talk Write untuk Meningkatkan Pemahaman Konsep IPA Siswa Kelas V SD N. 2 Melinggih Kelod. Widya Accarya, 10(Vol 10 No 2 (2019): Widya Accarya). https://doi.org/https://doi.org/10.46650/wa.10.2 $.770 . \% 25 p$

Winaya, I. M. A. (2020). PENGEMBANGAN NILAINILAI KARAKTER ANAK PADA PEMBELAJARAN JARAK JAUH DI MASA PADEMI COVID-19 DENGAN BERBANTU LEMBAR KEJA SISWA BERBASIS PROYEK. Jurnal Pendidikan Kewarganegaraan Undiksha, 8(1), 35-46. https://doi.org/http://dx.doi.org/10.23887/jpku. v8i3.28612

Winaya, I. M. A. dkk. (2018). Pengembangan Media Pembelajaran Berbasis Multimedia Interaktif dengan Konsep Tri Hita Karana untuk Pembelajaran Tematik di SD Kelas III Gugus 6 Kecamatan Abiansemal, Badung, Bali. Widya Accarya, 9(Vol 9 No 2 (2018):Widya Accarya), $1-14$.

https://doi.org/https://doi.org/10.46650/wa.9.2. $657 . \% 25 \mathrm{p}$ 